\title{
Management of Collar Rot Disease in Chili by Farmyard Manure and Commercial Biofertilizers
}

\author{
(Pengurusan Penyakit Pereputan Kolar dalam Cili oleh Baja Ladang dan Baja Biologi Komersial)
}

\author{
Nighat SANA*, AMnA SHOAIB \& ARSHAD JAVAID
}

\begin{abstract}
Collar rot of chili (Capsicum annuum L.) is a very destructive disease caused by a soil-borne fungal pathogen Sclerotium rolfsii Sacc. Generally, chemical fungicides are used to combat the menace but this practice is being discouraged because of health and environmental concerns. In the present study, an alternative environment friendly strategy was used to manage this disease by using farmyard manure (FYM) and two commercial biofertilizers namely Biopower and Feng Shou. S. rolfsii inoculated pot soil was amended with $1 \%$ and $2 \%$ FYM and the two commercial biofertilizers. Inoculation of soil with S. rolfsii only (positive control) resulted in the highest disease incidence (73\%) and plant mortality (60\%). Biopower and Feng Shou application reduced disease incidence to $20 \%$ and $7 \%$, respectively and plant mortality to $0 \%$. Likewise, $1 \%$ and $2 \%$ FYM amendment reduced disease incidence to $33 \%$ and plant mortality to $26 \%$ and $7 \%$, respectively. Under biotic stress of S. rolfsii, FYM and biofertilizers applications, either alone or in combination, significantly enhanced root and shoot growth over positive control. S. rolfsii inoculation significantly increased peroxidase and polyphenol oxidase activities in chili plants which were further increased by application of either of the two biofertilizers. The present study concludes that biofertilizers Biopower and Feng Shou alone or in combination with 2\% FYM can be effectively utilized to manage southern blight of chili.
\end{abstract}

Keywords: Capsicum annuum; fungal diseases; plant physiology; Sclerotium rolfsii

ABSTRAK

Pereputan kolar cili (Capsicum annuum L.) adalah penyakit pemusnah yang disebabkan patogen kulat bawaan tanah Sclerotium rolfsii Sacc. Secara umum, penggunaan baja bahan kimia adalah untuk menangani masalah ini tetapi amalan ini tidak digalakkan kerana kebimbangan kesihatan dan persekitaran. Kajian kini telah menggunakan alternatif strategi yang mesra alam dalam menguruskan penyakit ini dengan penggunaan baja ladang (FYM) dan dua baja biologi komersial iaitu Biopower dan Feng Shou. S. rolfsii diperkenalkan pada tanah pasu berserta $1 \%$ dan $2 \%$ FYM dan kedua-dua baja biologi komersial. Kehadiran S. rolfsii pada tanah mengakibatkan insiden penyakit tertinggi $(73 \%)$ dan kematian tumbuhan (60\%). Aplikasi Biopower dan Feng Shou mengurangkan kejadian penyakit kepada $20 \%$ dan $7 \%$ dan kematian tumbuhan pada 0\%. Begitu juga pengenalan 1\% dan $2 \%$ FYM telah mengurangkan insiden penyakit kepada $33 \%$ dan kematian tumbuhan kepada $26 \%$ dan $7 \%$. Di bawah tegasan biotik daripada aplikasi S. rolfsii, FYM dan baja biologi, sama ada secara bersendirian atau dalam kombinasi melalui kawalan positif dapat meningkatkan pertumbuhan akar dan pucuk secara ketara. Pengenalan S. rolfsii mengakibatkan peningkatan secara ketara kepada aktiviti peroksidase dan polifenol oksidase dalam tumbuhan cili dan akan terus meningkat dengan menggunakan salah satu daripada kedua-dua baja biologi ini. Kajian ini menyimpulkan bahawa baja biologi Biopower dan Feng Shou yang digunakan secara bersendirian atau dalam kombinasi dengan 2\% FYM boleh digunakan dengan berkesan dalam menguruskan cili hawar selatan.

Kata kunci: Capsicum annuum; fisiologi tumbuhan; penyakit kulat; Sclerotium rolfsii

\section{INTRODUCTION}

Chili (Capsicum annuum L.) is the world's most famous, nutritionally rich, widely used and valuable spice with 400 varieties cultivated around the globe. C. annuum is the most widely grown species that contribute to poverty alleviation by generating enormous revenues for producers (Karungi et al.2013). In Pakistan, C. annuum and C.frutescens are well-recognized and widely utilized. Pakistan is the 6th largest exporter of chili, hence it is cultivated on largest area (62.7 thousand ha) after potato and onion with an average yield of 2.7 tons ha-1 (GOP 2013). For a couple of years, the production and export of chili in Pakistan is declining mainly due to poor quality of seed, mal-culturing practice and diseases (Sahar et al. 2013). Collar rot disease caused by fungus Sclerotium rolfsii Sacc is becoming a threat to chili growing areas of Pakistan as well as the world due to fungus prevalence under diverse environmental conditions (Jabeen et al. 2014; Madhuri \& Gayathri 2014).

$S$. rolfsii is basidiomycete fungus that can infect over 500 plant species due to its prolific growth rate, while 
exhibits dual prevalence as aggressive seed and soil-borne pathogen. Generally, sclerotia and mycelium in soil can infect susceptible host at high temperature $\left(25-35^{\circ} \mathrm{C}\right)$ and high humidity (25-35\%) (Madhavi et al. 2011). The oxalic acid and tissue degrading enzymes of the fungus causes poisoning of plant. Mature infected plants of standing crop can collapse and suddenly die downward if host fails to respond or responds very slowly. Roots become shredded and unhealthy, with freshly infected area are being covered with white mycelium. After attack of $S$. rolfsii, the infected seedlings of chili die rapidly (Madhuri \& Gayathri 2014).

To date, different strategies opted against $S$. rolfsii have been proved ineffective due to melanised resting bodies (sclerotia) which exhibits potential to bear diversity of unfavorable conditions within the soil profile for potentially long periods. Drawback of various management strategies against $S$. rolfsii has altered the direction of scientists toward biorational alternative in the form of biofertilizers and organic manures. Such disease management methods are generally less expensive, self-maintaining, long-lasting, durable and hold high antifungal activity as compared to chemical fungicides (Bhattacharjee \& Dey 2014) and has paved the way toward sustainable agriculture. Biofertilizers generally composed of Pseudomonas, Bradyrhizobium, Rhizobium and Trichoderma have been found to suppress $S$. rolfsi through antibiosis, production of toxic metabolites and siderphores. In Pakistan, biofertilizers are being prepared with different trade names. It is speculated that the microorganisms in different commercial biofertilizers available in local market are meant to improve plant growth through different mode of actions including induction of resistance in the plant against targeted pathogens. One such product is Biopower that is comprised of efficient strains of Azorhizobium, Rhizobium, Pseudomonas, Bradyrhizobium and Azospirillum. These microorganisms can enhance plant growth by solubilizing phosphorous, mobilizing zinc, producing bacteriocin and phytohormones. Another such product is Feng Shou, which is composed of plant growth hormone producing bacteria along with Azospirillum and Azotobacter. Therefore, it is important to explore the role of such kind of microbial inoculants against collar rot pathogen of chili. So far, another disease management option could be applied through exploring role of organic soil amendments like animal manures (e.g. farmyard manure). It was illustrated that many antifungal compounds released during organic matter decomposition may induce systemic resistance in the host plants against phytopathogens (Abdel-Fattah \& Al-Amri 2012). Accumulation of ammonia and nitrous acid released from nitrogenous amendments was reported to suppress the soil-borne pathogen like Verticillium dahlia (Bonilla et al. 2012). Therefore, the present investigation was conducted to manage collar rot of chili by using farmyard manure (FYM) and two commercial biofertilizers namely Biopower and Feng Shou.

\section{MATERIALS AND METHODS}

The pathogenicity test of $S$. rolfsii was checked on chili var. Tatapuri by mixing freshly prepared conidial suspensions $\left(30 \times 10^{5}\right.$ conidia $\left.\mathrm{mL}^{-1}\right)$ in sterilized $(500 \mathrm{~g})$ soil filled in plastic pots followed by sowing of 5 seeds of the test plant species per pot. Uninoculated pots served as control treatment for comparison. There were ten replicates of each treatment. Typical symptoms of collar rot disease were observed on chili plants by using 0-3 rating scale (Horsfall \& Barratt 1945) after 4 weeks of germination.

Sandy loam soil having $\mathrm{pH} 7.5$, nitrogen $0.046 \%$, exchangeable potassium $100 \mathrm{mg} \mathrm{kg}^{-1}$ and available phosphorus $6.6 \mathrm{mg} \mathrm{kg}^{-1}$ was utilized to conduct pot trials. Formalin was used to sterilize soil. Pre-sterilized soil (4 $\mathrm{kg}$ ) was filled in each pot (25 cm diameter, $30 \mathrm{~cm}$ height) and was inoculated with inoculum of $S$. rolfsii. Preinoculated soil with $S$. rolfsii was utilized to assess effect of biofertilizers and FYM on disease, plant growth and physiology.

Biofertilizer 1 (Biopower) was provided by National Institute for Biotechnology and Genetic Engineering (NIBGE), Faisalabad, Pakistan. Biofertilizer 2 (Feng Shou) was a liquid bacterial culture, manufactured by Green life Bioscience, Bogor Indonesia. Feng Shou was purchased from Local market of Lahore, Pakistan. Biofertilizer 1 (BF 1) was prepared by mixing its $100 \mathrm{~g}$ in $1 \mathrm{~L}$ of water, while Biofertilizer 2 (BF 2) was made by adding its $100 \mathrm{~mL}$ in $1 \mathrm{~L}$ of water. Inoculum of each biofertilizer was given to roots separately by dipping roots of chili seedlings for 30 min before transplantation.

Farmyard manure (FYM) was thoroughly mixed at $1 \%$ and $2 \%$ on dry weight basis in sterilized pot soil already inoculated with $S$. rolfsii. Pots were watered and left for 10 days for establishment of conditions. After that 5 chili seedlings (at 4-5 leaf stage) were transplanted in each pot. There were 12 treatments with three replicates and the experiment was performed in completely randomized design. Negative control deprived of any application, a positive control with $S$. rolfsii (SR) inoculation in unamended soil, Biopower (BF1), Feng Shou (BF2), BF1 $+\mathrm{SR}, \mathrm{BF} 2+\mathrm{SR}, 1 \% \mathrm{FYM}+\mathrm{SR}, 1 \% \mathrm{FYM}+\mathrm{SR}+\mathrm{BF} 1,1 \%$ $\mathrm{FYM}+\mathrm{SR}+\mathrm{BF} 2,2 \% \mathrm{FYM}+\mathrm{SR}, 2 \% \mathrm{FYM}+\mathrm{SR}+\mathrm{BF} 1$ and $2 \% \mathrm{FYM}+\mathrm{SR}+\mathrm{BF} 2$.

Experiment was carried out for 105 days after transplanting chili seedlings. Physiological assays of the chili leaves were carried out after 60 days of transplantation. Total chlorophyll content was extracted by grinding fresh leaf material $(500 \mathrm{mg})$ in $10 \mathrm{~mL}$ of chilled $80 \%$ ethanol and centrifuging homogenate at $3000 \mathrm{rpm}$. Absorption of resultant supernatant was examined at 645 and $663 \mathrm{~nm}$ and total chlorophyll content was calculated (Lichtenthaler \& Buschmann 2001). Total protein content of the leaf was determined by method of Lowry using Bovine Serum Albumen (BSA) as standard (Lowry et al. 1951). Methods of Kumar and Khan (1982) and Mayer et al. (1965) were used for assessment of peroxidase (PO) and polyphenol oxidase (PPO), respectively. 
Relevant data of disease incidence, plant mortality and plant growth attributes (length, fresh and dry biomass of root and shoot) were taken. Shoot biomass included leaves, stems and fruits. Analysis of variance (ANOVA) was used to statistically analyze data and least significant difference (LSD) test was applied for means comparison using Statistics 8.1.

\section{RESULTS AND DISCUSSION}

\section{DISEASE INCIDENCE, PLANT MORTALITY AND GROWTH}

Disease incidence and plant mortality were the highest in positive control. All the treatments variably and significantly reduced disease incidence and plant mortality by $54-90 \%$ and $56-100 \%$ over positive control, respectively. Treatments $\mathrm{BF} 2+\mathrm{SR}, 1 \% \mathrm{FYM}+\mathrm{SR}+\mathrm{BF} 2$ and $2 \% \mathrm{FYM}+\mathrm{SR}+\mathrm{BF} 2$ exhibited the lowest disease incidence and plant mortality indicating that $\mathrm{BF} 2$ is more effective than BF 1 in the management of collar rot disease of chili (Figure 1(a) \& 1(b)).

$S$.rolfsii inoculation reduced length, fresh weight and dry weight of root by $19 \%, 30 \%$ and $40 \%$ over negative control, respectively. BF $1+\mathrm{SR}, 1 \% \mathrm{FYM}+\mathrm{SR}, 2 \% \mathrm{FYM}+$
$\mathrm{SR}+\mathrm{BF} 1$ and $2 \% \mathrm{FYM}+\mathrm{SR}+\mathrm{BF} 2$ treatments significantly enhanced shoot length over positive control. In general, all the treatments enhanced shoot dry biomass to variable extents over positive control. The effect of $1 \%$ FYM + $\mathrm{SR}$ and $2 \% \mathrm{FYM}+\mathrm{SR}+\mathrm{BF} 1$ was significant where $87 \%$ and $92 \%$ increase in shoot dry weight was recorded over positive control, respectively (Figure 2(a)-2(c)).

There was $32 \%, 13 \%$ and $31 \%$ decrease in root biomass due to $S$. rolfsii inoculation over negative control. In general, all the treatments variably enhanced various root growth parameters. The effect of $2 \% \mathrm{FYM}+\mathrm{SR}+\mathrm{BF}$ 2 treatment was the most pronounced and significant. This treatment increase root length and dry biomass by $80 \%$ and $111 \%$ over positive control, respectively. Likewise, other treatments viz. BF $2+$ SR and 1\% FYM + SR also increased root biomass significantly over control (Figure 3(a)-3(c)).

Pathogenicity of $S$. rolfsii in different host plants due to production of toxins and acids is well-known. Lecithinases or phosphatidases have been suggested as possible toxin responsible for pathogenicity in host cell that probably change plasma membrane permeability of the infected host (Tseng \& Bateman 1970). Alteration in membranes permeability could increase respiration rate with disruption of normal functioning of infected chili plant followed by
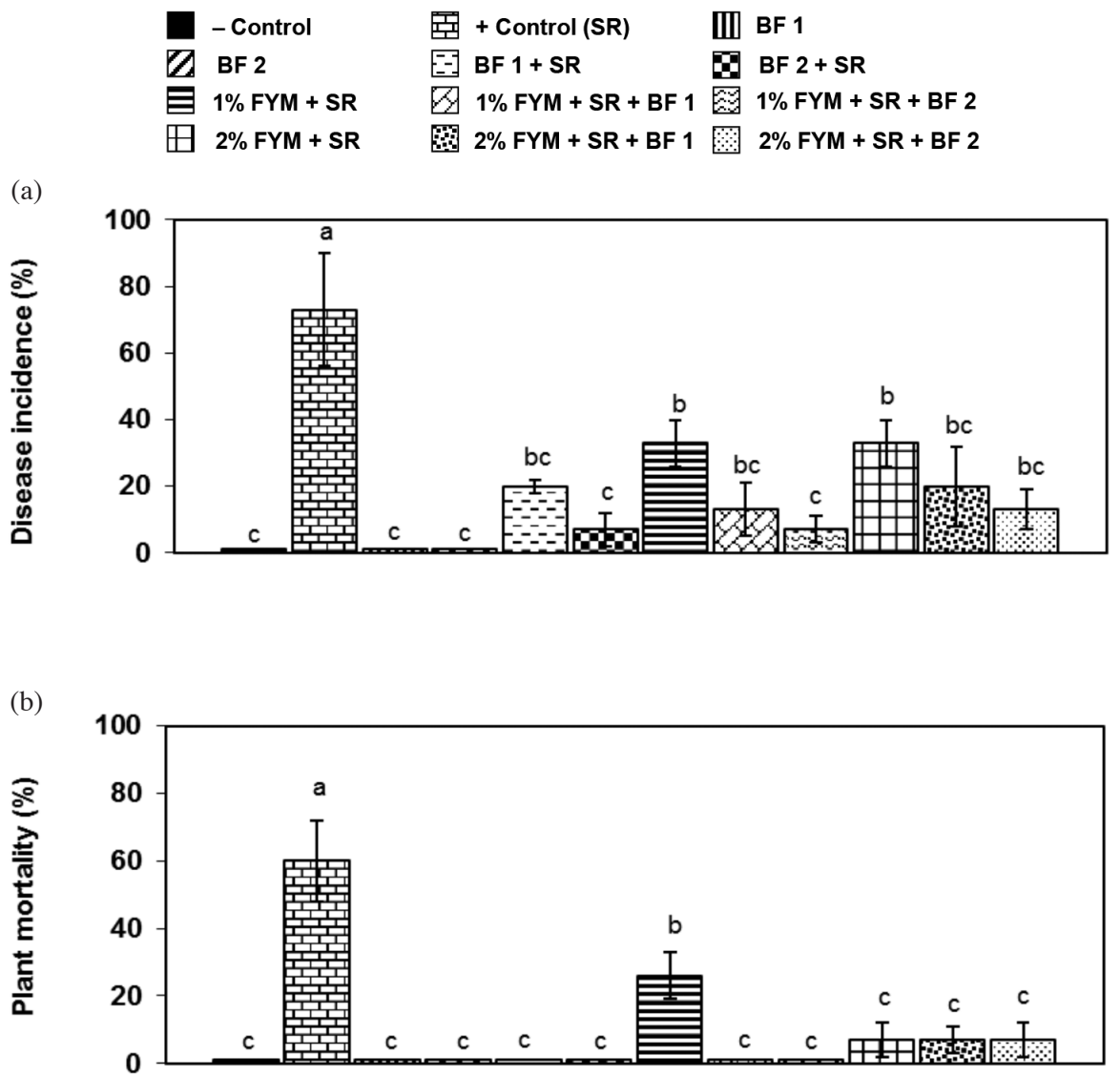

Vertical bars show standard errors of means of three replicates. Values with different letters at their top show significant difference $(p \leq 0.05)$ as determined by LSD Test. BF 1: Biopower; BF 2: Feng Shou

FIGURE 1. Effect of farmyard manure (FYM) and biofertilizers (BF) on disease incidence

(a) and plant mortality (b) in chili due to Sclerotium rolfsii (SR) 

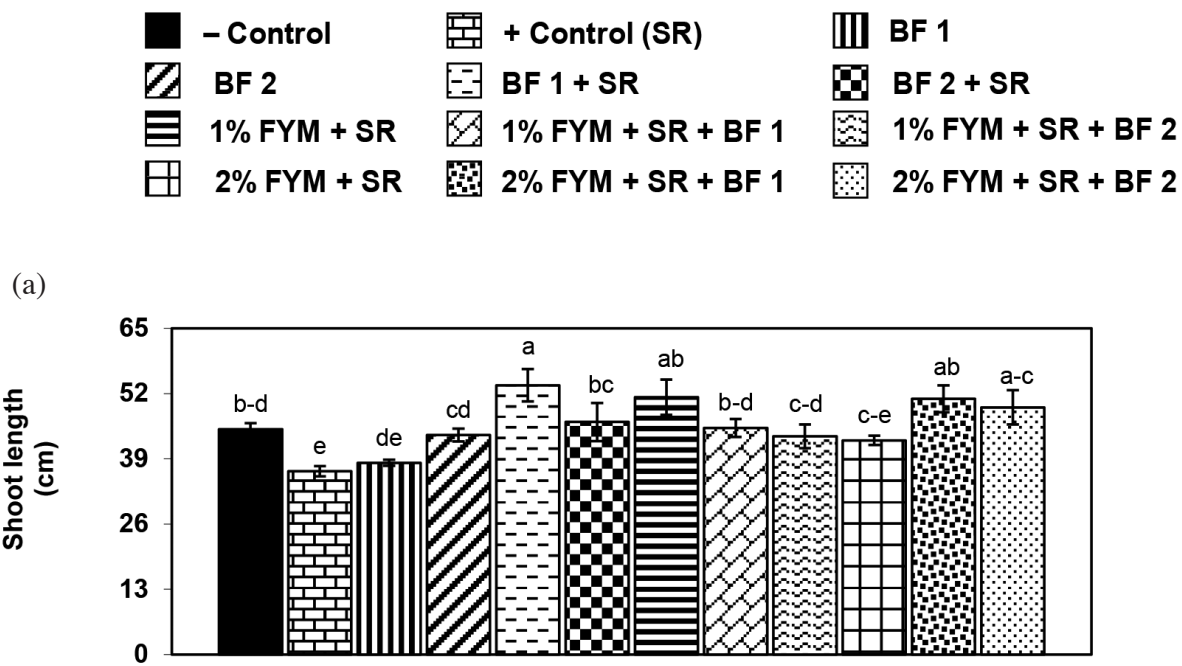

(b)
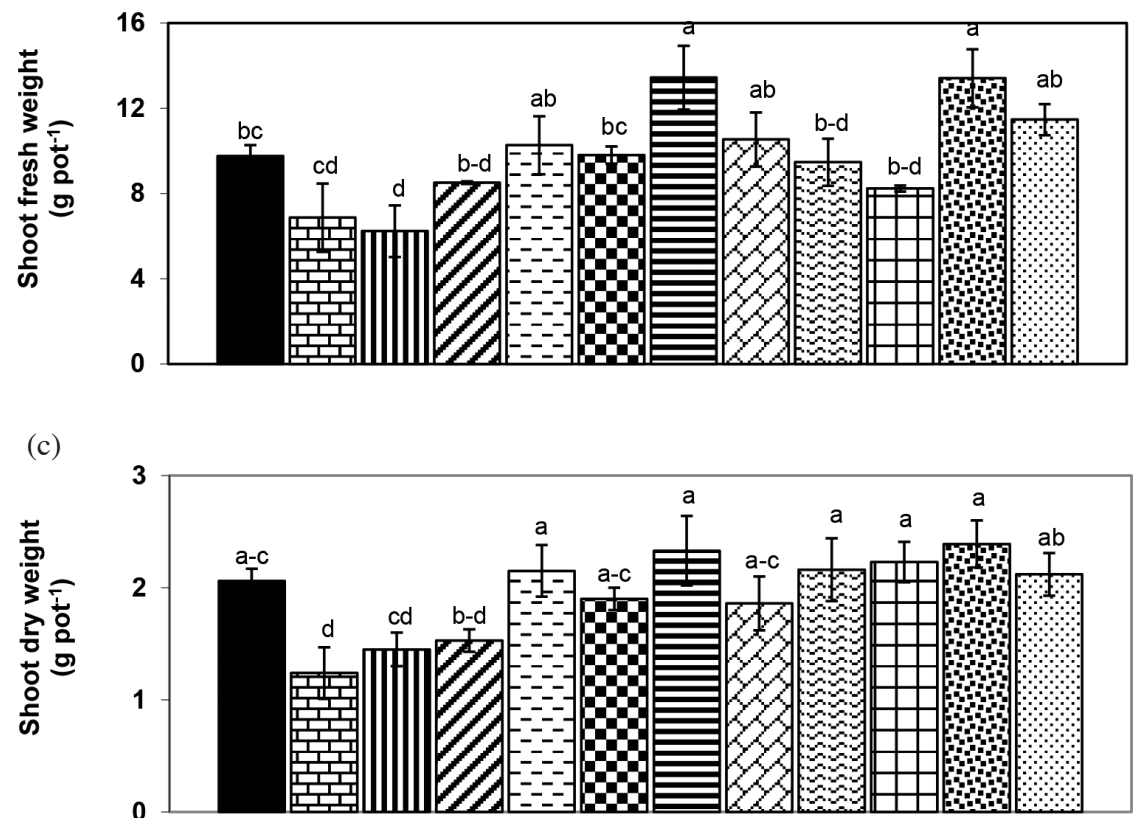

Vertical bars show standard errors of means of three replicates. Values with different letters at their top show significant difference $(p \leq 0.05)$ as determined by LSD Test. BF 1: Biopower; BF 2: Feng Shou

FIGURE 2. Effect of Sclerotium rolfsii (SR), farmyard manure (FYM) and biofertilizers (BF) on shoot growth of chili

increase in disease incidence, plant mortality and decrease in plant growth (Madhuri \& Gayathri 2014). However, treatment of chili root with both biofertilizers significantly improved plant growth by decreasing disease incidence and plant mortality. Different microorganisms in biofertilizers generally function by increasing nutrient supply or by altering plant hormone levels (Gupta et al. 2015). Therefore, microorganisms in biofertilizers formulation likely to exhibit antifungal action through production of chitinase, siderophores, ammonia, hydrogen cyanide and volatile antibiotics (Abou-Aly-He et al. 2015). Moreover, induction of resistance in chili plant may cause production of jasmonate and ethylene signaling by microorganisms in biofertilizers (Glick 2012). BF2 exhibited more pronounced results as compared to BF1, by reducing disease incidence and plant mortality with enhancement in chili plant biomass. It seems that microorganisms in BF1 were less efficient in producing indole acetic acid and gibberellic acid required during initial stage of plant to promote growth in comparison to BF2. Besides, the carrier material may also affect activity of microorganisms in biofertilizers (Asdad et al. 2004).

The results showed that $2 \%$ FYM hold more potential to minimize the stress of $S$. rolfsii in comparison to $1 \%$ FYM by improving chili biomass. Increase in plant growth and biomass was also reported previously with increase in 


\begin{tabular}{|c|c|c|}
\hline - Control & 臣 +Control (SR) & IIII BF 1 \\
\hline BF 2 & BF 1 + SR & B BF $2+S R$ \\
\hline SR & $1 \% F Y M+S R+B F 1$ & ح $1 \% F Y M+S R+B F 2$ \\
\hline $2 \%$ FYM + SR & $2 \% F Y M+S R+B F 1$ & $2 \% F Y M+S R+$ \\
\hline
\end{tabular}
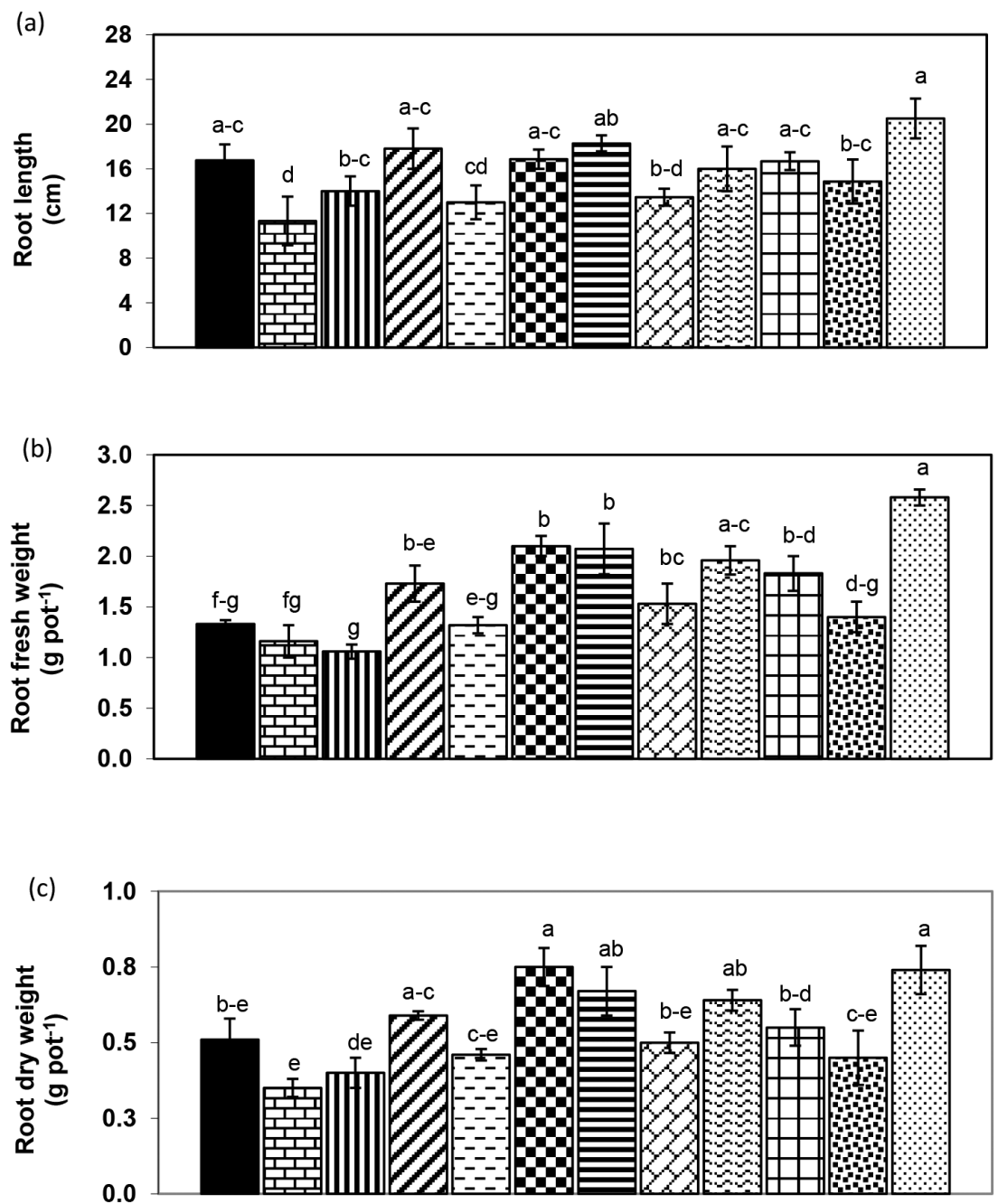

Vertical bars show standard errors of means of three replicates. Values with different letters at their top show significant difference ( $p \leq 0.05)$ as determined by LSD Test. BF 1: Biopower; BF 2: Feng Shou

FIGURE 3. Effect of Sclerotium rolfsii (SR), farmyard manure (FYM) and biofertilizers (BF) on root growth of chili

amount of FYM and was attributed to the quick and readily availability of major nutrients like $\mathrm{N}, \mathrm{P}$ and $\mathrm{K}$ to plants at the stages of plant growth, which might have enhanced cell division and cell elongation (Reddy 1999). Soil mixing with FYM along with both biofertilizers significantly minimized disease incidence and plant mortality as well could be owing to intensification in activity of antagonistic microorganisms (Cwalina-Ambroziak \& Wierzbowska 2009). Moreover, a positive interaction between FYM and biofertilizers seems to work synergistically by improving physical and chemical properties of soil that probably consequences in increase in nutrients uptake by chili plant with better growth and biomass and lessen disease (Basso \& Ritchie 2005).

\section{PLANT PHYSIOLOGY}

$S$. rolfsii inoculation significantly reduced chlorophyll content by $49 \%$ over negative control. BF 2 treatments markedly enhanced chlorophyll content by $80 \%$ over negative control. The effect of other treatments on this parameter was generally insignificant or significantly lower than positive control (Figure 4(a)). Reduction in total chlorophyll content due to infection of $S$. rolfsi may be explained by inhibition of fungal toxins on photophosphorylation (Lubaina \& Murugan 2013). Improvement in total chlorophyll content due to biofertilizers and FYM could be due to increase in nutrients availability to chili plant with better outcome on overall growth. 

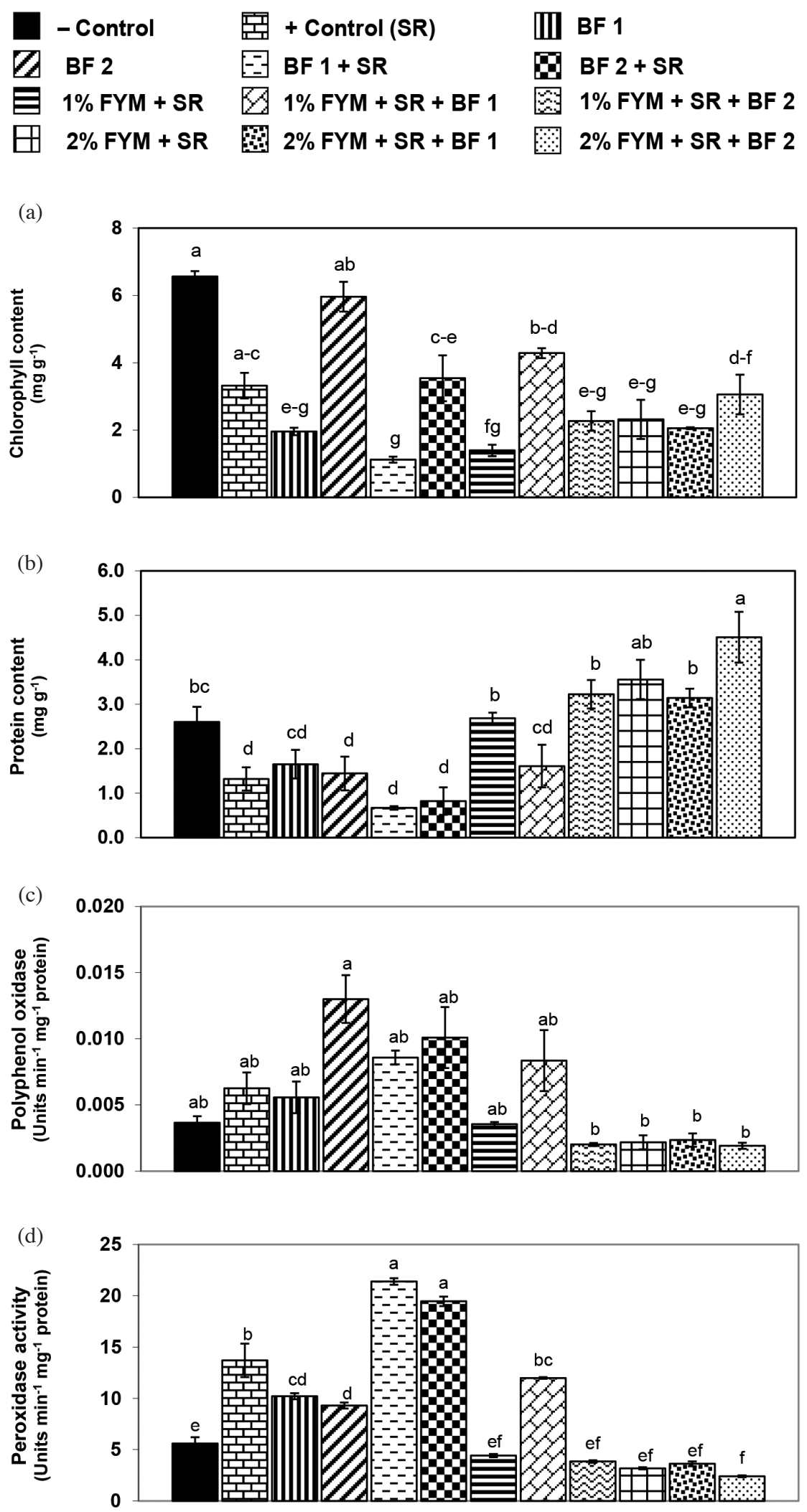

Vertical bars show standard errors of means of three replicates. Values with different letters at their top show significant difference $(p \leq 0.05)$ as determined by LSD Test. BF 1: Biopower; BF 2: Feng Shou

FIGURE 4. Effect of Sclerotium rolfsii (SR), farmyard manure (FYM) and biofertilizers $(\mathrm{BF})$ on various physiological parameters of chili 
Protein contents were significantly reduced by $49 \%$ due to $S$. rolfsii inoculation. BF 2 in combination with either $1 \%$ or $2 \%$ farmyard manure significantly enhanced protein contents over negative control. Likewise, the effect of $2 \%$ FYM with or without BF 1 was also significant over positive control (4(b)). Reduction in protein content of infected plant may indicate protein denaturation or its utilization by host during defense mechanism (Lubaina \& Murugan 2013). Increase in total protein content was an indication of activation of host defense system in chili seedlings due to application of biofertilizer and FYM application.

Inoculation of $S$. rolfsii increased PPO activity by $71 \%$ that was further enhanced in $\mathrm{BF} 1, \mathrm{BF} 2, \mathrm{BF} 1+\mathrm{SR}$ and $1 \%$ $\mathrm{FYM}+\mathrm{SR}+\mathrm{BF} 1$ treatment. In contrast, this parameter was reduced in treatments where BF 2 was applied in combination with either of the two doses of FYM (Figure 4(c)). The effect of $S$. rolfsii, biofertilizers and different doses of FYM on PO activity was generally similar to the effect of these amendments on PPO activity (Figure 4(d)). PPO is oxidative enzyme that through conversion of phenolic compounds of plants to polyphenols and quinines produce toxic substances against extracellular enzymes of pathogens. Increase in activity of PPO may indicate activation its role in triggering the hypersensitive reaction (HR) in chili plant. Involvement PO in last enzymatic step of lignin biosynthesis and production of active oxygen species is well-known (Nandi et al. 2013). Increase activity of PO could be linked with its role in reducing pathogen viability and spread.

\section{CONCLUSION}

It was concluded that biofertilizers Biopower and Feng Shou alone or in combination with $2 \%$ FYM could be used to control collar rot of chili caused by $S$. rolfsii through induction of resistance in plant.

\section{REFERENCES}

Abdel-Fattah, G.M. \& Al-Amri, S.M. 2013. Systemic resistance in tomato plants against Fusarium oxysporium f. sp. lycopersici by different kinds of compost. African Journal of Biotechnology 11: 12454-12463.

Abou-Aly, H.E., Neweigy, N.A., Zaghloul, R.A., El-Sayed, S.A. \& Bahloul, A.M. 2015. Evaluation of some biocontrol agents against soil pathogenic fungi. Research Journal of Pharmaceutical, Biological and Chemical Sciences 6: 440.

Asdad, S.A., Bano, A., Farooq, M., Aslam, M. \& Afzal, A. 2004. Comparative study of the effects of biofertilizers on nodulation and yield characteristics of mung bean (Phaseolus vulgaris L.). International Journal of Agriculture and Biology 6: 837-848.

Basso, B. \& Ritchie, J.T. 2005. Impact of compost manure and inorganic fertilizer on nitrate leaching and yield for a 6 year maize alfalfa rotation in Michigan. Agriculture, Ecosystems and Environment 108: 309-341.

Bhattacharjee, R. \& Dey, U. 2014. Biofertilizer, a way towards organic agriculture: A review. African Journal of Microbiology Research 8: 2332-2343.
Bonilla, N., Gutiérrez-Barranquero, J.A., Vicente, A.D. \& Cazorla, F.M. 2012. Enhancing soil quality and plant health through suppressive organic amendments. Diversity 4: 475491.

Cwalina-Ambroziak, B . \& Wierzbowska, J. 2009. Contemporary problems of management and environmental protection. Sewages and Waste Materials in Environment 4: 107-118.

Glick, B.R. 2012. Plant growth-promoting bacteria: Mechanism and Application. Scientifica. Article ID. 963401. doi: 10.6064/2012/963401.

Government of Pakistan (GOP). 2013. Economic Survey of Pakistan, 2012-2013. Finance division Economic Advisor's Wing, Islamabad.

Gupta, S., Sharma, P., Dev, K., Srivastava, M. \& Sourirajan, A. 2015. A diverse group of halophilic bacteria exist in Lunsu, a natural salt water body of Himachal Pradesh. India. Springer Plus 4: 274.

Horsfall, J.G. \& Barratt, R.W. 1945. An improved grading system for measuring plant diseases. Phytopathology 35: 655.

Jabeen, N., Javaid,A.,Ahmed, E. \& Sharif,A. 2014. Management of causal organism of collar rot of bell pepper (Sclerotium rolfsii) by organic solvents extracts of Datura metel fruit. Pakistan Journal of Phytopathology 26: 15-20.

Karungi, J., Obua, T., Kyamanywa, S., Mortensen, C.N. \& Erbaugh, M. 2013. Seedling protection and field practices for management of insect vectors and viral diseases of hot pepper (Capsicum chinense Jacq.) in Uganda. International Journal of Pest Management 59: 103-110.

Kumar, K.B. \& Khan, P.A. 1982. Peroxidase and polyphenol oxidase in excised ragi (Eleusine coracana cv. PR 202) leaves during senescence. Indian Journal of Experimental Botany 20: 412-416.

Lichtenthaler, H.K. \& Buschmann, C. 2001. Current Protocols in Food Analytical Chemistry. New York: John Wiley and Sons Inc. Units: F4.3.1-F4.3.8.

Lowry, O.H., Rosenbrough, N.J., Farr, A.L. \& Randall, R.J. 1951. Protein measurement with the folin phenol reagent. The Journal of Biological Chemistry 193: 265-275.

Lubaina, A.S. \& Murugan, K. 2013. Ultrastructural changes and oxidative stress markers in wild and cultivar Sesamum orientale L. following Alternaria sesami (Kawamura) Mohanty and Behera inoculation. Indian Journal of Experimental Biology 51: 670-680.

Madhavi, B.G. \& Bhattiprolu, S.L. 2011. Integrated disease management of dry root rot of chilli incited by Sclerotium rolfsii (Sacc.). International Journal of Plant, Animal and Environmental Sciences 2: 31-37.

Madhuri, V. \& Gayathri, D.A. 2014. Root rot of chili incited by Sclerotium rolfsii Sacc. and its management. A review. International Journal of Applied Biology and Pharmaceutical Technology 5: 197-204.

Mayer, A.M., Harel, E. \& Shaul, R.B. 1965. Assay of catechol oxidase, a critical comparison of methods. Phytochemistry 5: 783-789.

Nandi, S., Dutta, S., Mondal, A., Adhikari, A., Nath, R., Chattopadhaya, A. \& Chaudhuri, S. 2013. Biochemical responses during the pathogenesis of Sclerotium rolfsii on cowpea. African Journal of Biotechnology 12: 3968-3977.

Reddy, V.C. 1999. Effect of urban garbage compost on growth and yield of tomato. Current Research 28: 43-44.

Sahar, N., Arif, S., Afzal, Q., Ahmed, M., Ara, J. \& Chaudhry, Q. 2013. Impact of discoloration and picking practices of 
red chilies on aflatoxin levels. Pakistan Journal of Botany 45: 1669-1672.

Tseng, T.C. \& Bateman, A. 1969. Phosphatidases produced by Sclerotium rolfsii. Phytopathology 59: 359-363.

Institute of Agricultural Sciences

University of the Punjab, Lahore

Pakistan
*Corresponding author; email: aamnaa29@yahoo.com

Received: 7 March 2016

Accepted: 14 March 2017 